\title{
POESIA E MAGIA
}

\section{José Fernandes}

\section{RESUMO}

Este estudo visa a mostrar, mediante a análise de componentes esotéricos ligados à cabala $\mathrm{e}$ à mandala, como a estrutura de poemas visuais gregos $\mathrm{e}$ de talismãs hebraicos, mesmo criados com intençōes religiosas, voltadas para a magia, seguem um engenho próprio do texto poético.

Ao debruçarmo-nos sobre os poemas visuais da antiguidade, defrontamo-nos, de imediato, com alguns obstáculos, mormente de ordem hermenêutica, derivados da associação intrínseca da arte, máxime a moldura poética das imagens, com a mitologia que permeava a estética e a filosofia da maioria dos povos antigos. Atendo-nos, neste artigo, a produções grega e hebraica, vamos observar que eles viam os fenômenos naturais e a criação artística como fruto da participação das divindades, porque, para eles, a mente se sobrepunha à matéria. Como conseqüência, o texto artístico era resultante de um misto de razāo e de magia. Dissociá-las é impossível, uma vez que as crenças mágicas (...) foram revestidas pelos filósofos com as belas roupagens da razão. ${ }^{1}$

A estas dificuldades, acrescem-se as imbricações culturais, obrigando-nos a caminhar nos labirintos de símbolos e de mitologias que, muitas vezes, tornam o acesso aos significados quase impossível, a ponto de Ana Hatherly acentuar que: Se a origem da maior parte da poesia figurada européia é hoje atribuída sem hesitaçāo à tradição grega alexandrina, que está ligada ao hermetismo greco-romano e ao neo-platonismo, a origem dos anagramas e doutras composiçōes de caráter combinatório, derivando também em parte a tradição grega (por via pitagórica), está porém muito mais intimamente ligada ao cabalismo hebraico, que se desenvolveu a partir de uma época aproximadamente contemporânea do hermetismo helenístico ${ }^{2}$. A conjunção das culturas, em conseqüência, vai contribuir

- Professor Tîtular de Literatura Brasileira da UFG. Doutor em Literatura Brasileira e membro da Academia Goiana de Letras.

1 - SELIGMANN, K. (1979), p. 67

2 - HATHERLY, A. (1983), p. 17.

Signótica 4: 47-60, jan./dez. 1992 
sobejamente para que o poema, que em si já visa à criação de um enigma, venha a se tornar ainda mais hermético.

Se considerarmos, ainda, que, afora o acoplamento de culturas antigas, aderem-se também razões ideológicas que obrigam a se recorrer a procedimentos capazes de encobrir enigmas interditos ao poder, o hermetismo se envereda por direçōes ainda mais impenetráveis ao entendimento comum do hermeneuta.

\section{1 - SOB O SIGNO DE HERMES}

Hermetismo, não obstante parecer uma contradição, provém de Hermes, o deus que imaginou a palavra, o mensageiro. De certa maneira, o poema Ovo (300 a.C.), de Símias de Rodes, constitui uma apologia àquele que teceu o discurso, a nova trama de uma mãe gorjeante. Como o poema visa a mostrar, ou a esconder, as artimanhas da própria construção, o poeta não podia deixar de erigi-lo sob o signo de Hermes. Se atentarmos para o primeiro verso, formado pela palavra Kwtî̄os (Kotilas) ${ }^{3}$, percebemos Hermes a enredar as palavras, porque charlatão e tagarela traduzem bem o caráter falseador, astuto, do mensageiro dos deuses. Sob esta perspectiva, a nova trama ou o novo tecido (âtpเov véov), construído(a) por uma mãe gorjeante $(\mu \alpha \tau \rho \delta \varsigma \lambda i \gamma \varepsilon \backsim \alpha)$, nada mais é que o próprio texto, distribuído aos homens pelo tonitroante Hermes (غे $\iota_{\beta \sigma o \zeta}$ E $\left.\rho \mu \alpha \varsigma\right)$. Ora, Hermes, conforme postulações de Sócrates-Platão, se confunde com o próprio discurso em sua totalidade sígnica e significativa: os caracteres de intérprete (hermeneus), de mensageiro, de ladrāo astuto, de falseador de palavras e hábil comerciante supōem todos uma atividade que se reduz às palavras e ao poder do discurso. ${ }^{4}$

Conquanto parecer clara a atividade extorsiva de Hermes, ao arrebatar o discurso de sua querida mãe ( $\phi \mathrm{t} \lambda \circ \varsigma \mu \alpha \tau \rho \delta \varsigma)$ e lançá-lo no meio das tribos dos homens, o texto revela, à primeira vista, toda sua astúcia de falsear e de tecer palavras. O poeta à sua semelhança, camufla os signos ao elaborar um poema simultaneista, de tal forma que tenhamos a seqüência a partir da primeira e da última linha até a medida de dez, ou seja, até chegar aos dois versos mais extensos, que correspondem ao décimo de cima para baixo e de baixo para cima. Temos, assim, um discurso hermético in se, porque se fecha como que formando dois triângulos. Não se trata apenas de um hermetismo semântico, mas, sobretudo, de um fechamento

3 - A traduçāo do vocábulo nāo figura na versāo inglesa da revista Art News Annual, de onde retiramos o poema. Como a traduçâo portuguesa procurou segui-la, quase ao pé da letra, o vocábulo ficou sacrificado. Todavia, para a análise é ele fundamental.

4 - PLATON. (1979), p. 527. 
semiótico, porquanto é o poema erigido de fora para dentro, compondo um objetosigno todo significativo:

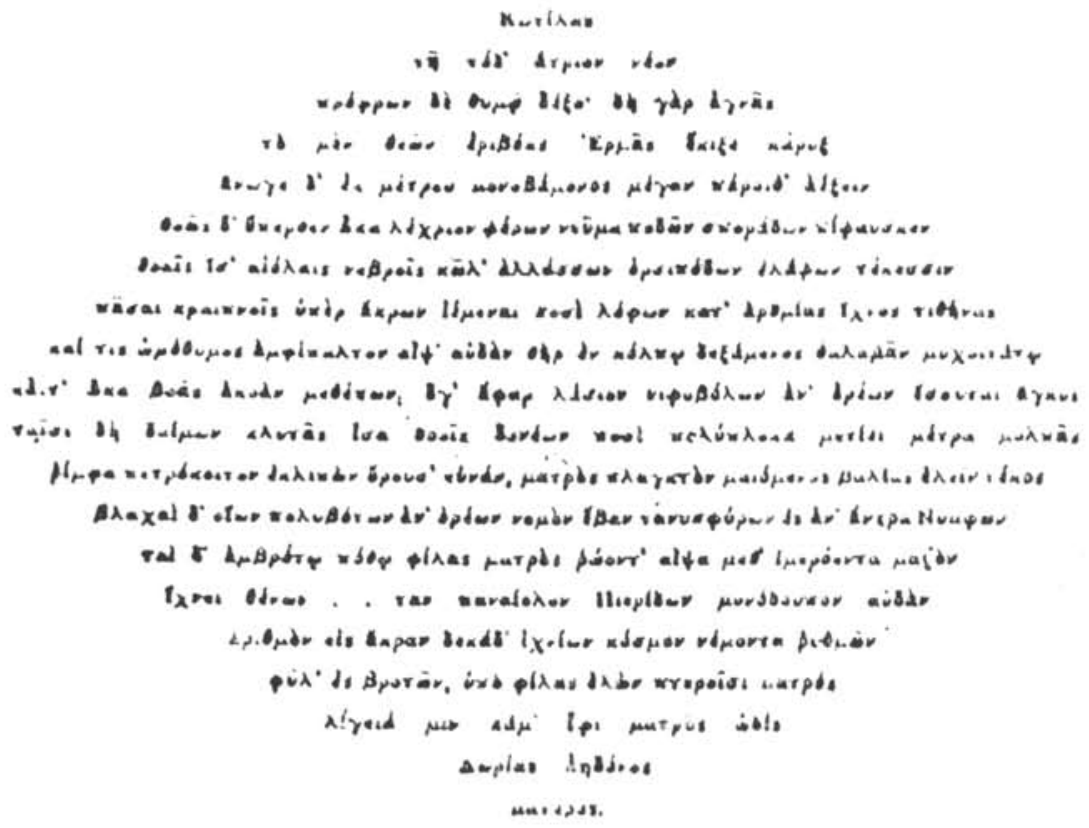

5 - SIMIAS, R. In BOULTENHOUSE, C. (1959), p. 67.

Eis aqui uma nova trama de uma mäe gorjeante, um rouxinol dórico; recebe-a com um ânimo verdadeiramente bom; pois imaculada era a mäe cuja dor pungente teceu-a. O tonitroante Hermes, o arauto dos deuses, arrebatou-a de debaixo das asas de sua querida mãe e lançou-a no meio das tribos dos homens e mandou-a multiplicar-se mais e mais; aquele número conservando o tempo adequado da ordem dos ritmos - desde a medida de um pé até as medidas completas de dez: e logo fertilizou lá de cima a encosta inesperadamente inclinada de seus pés errantes, atingindo, à medida que avançava, não só um estilo verdadeiramente colorido, mas também um grito adequadamente harmonioso das Musas Piérides, e trocando de membros com os cervos ágeis os rebentos velozes dos veados de pés agitados. Agora esses cervos, através de um desejo imortal de sua querida mäe, correm velozmente para as tetas amadas, todos passando com os pés apressados sobre o cimo dos montes na trilha daquela afável guardiä, e com um balido eles väo pelas pastagens da montanha das mil ovelhas nutrizes e pelas grutas das Ninfas de tornozelos delgados, até que de repente alguma besta de coração cruel, recebendo seu grito ecoante no redil de sua toca, lança-se velozmente do leito de seu covil rochoso na intenção de pegar um dos rebentos vagantes daquela mãe malhada, e então prontamente seguindo o som de seu grito, chispa através do vale desgrenhado das montanhas vestidas de neve. De pés tão ligeiros quanto as deles exigiu aquele célebre Deus o trabalho, enquanto acelerava as medidas múltiplas da canção. 
As medidas dos pés, antes de figurarem como componentes esotéricos, revelam a afirmação de uma postura filosófica que vê nos números a constituição do próprio universo. Se o universo é uma combinação de números ${ }^{6}$, um poema tecido segundo a astúcia de Hermes e que deve ser modelo para os deusespoetas, também deve pautar pela medida. Sob este prisma, a progressão dos pés até a medida completa de dez não configura um capricho da técnica grega de escansão, mas obedece a um princípio que rege, inclusive, a harmonia do universo. As duas direções, ascendente e descendente, partem da unidade simples para a unidade composta e vice-versa. A presença do número 1 nas duas extremidades, caminhando para a unidade complexa representa, usando palavras de René Allendy, o ponto de partida, agente dinâmico que caminha para uma estado estático que exprime o equilíbrio realizado na unidade ${ }^{7}$. Ora, na concepção grega de estética, este equilíbrio nada mais é que a simetria, a aproximação das artes com as matemáticas, como propusera Aristóteles: Com efeito, as formas mais estimadas do belo são a ordem, a simetria e a limitação, coisas que dão a conhecer em alto grau as ciências matemáticas $^{8}$. Mesmo que esta ordem se multiplique, através dos pés dos cervos ágeis, é imperioso que a unidade seja mantida, porque é ela a consciência do logos, ou seja, do discurso-tecido sendo.

Quando o movimento passa dos pés de Hermes para os pés dos cervos, observamos a passagem do uno para o múltiplo, uma vez que o tecido sai da órbita dos deuses e dos homens e se transfere para a órbita dos animais e dos objetos. É o momento em que as coisas saem do caos da inominação e se lançam na existência, porque essencialmente determinadas pelo nome. Neste contexto, a seqüência numérica fechada no denário configura o eterno retorno à unidade, à mãe ( $\mu \alpha \tau \varepsilon \rho \varsigma)$ ) e reflete bem a circularidade do poema, indo e voltando sobre si mesmo. Como os tecidos do discurso, a volta implica sempre passagens pelas encostas inclinadas dos pés errantes, ou seja, pelo hábil falseador de palavras e forjador de nova trama. $\mathrm{O}$ ir-e-vir dos números da unidade à unidade representa a incomum capacidade de renovação da palavra, uma vez que o denário não somente é um número perfeito, pois constitui o total dos quatro primeiros algarismos, mas, máxime porque é ele um número circular. Seguindo esta interpretação, não é sem razão que a palavra anfipalton ( $\not \mu \phi \iota \tau \alpha \lambda \tau \mathrm{\tau ov})$, lançado ao redor, se encontra exatamente no décimo verso descendente, como a confirmar a circularidade do número e do poema.

Ao permitir que a palavra, trama ( $\alpha \tau \rho\llcorner o v)$ se multiplique até dez, ou seja, até o uno e o múltiplo, fica claro o sentido de totalidade, consubstanciado pela inerente perfeição do denário, resultante da soma dos quatro primeiros

6 - ARISTÓTELES. (1973), p. 917.

7 - ALLENDY, R. (1984), p. 288

8 - ARISTÓTELES. (1973), . 1065 
algarismos, $1+2+3+4=10$. Não nos esquecendo de que este poema encerra postulaçōes da filosofia grega, confirmadas pela ação de Hermes, o deus da revelação, o spiritus vitae ${ }^{9}$, ou seja, da criação, vamos verificar que, para os pitagóricos, o denário é a própria criação. Se tudo dela deriva, tudo a ela retorna. Ela materializa, em conseqüência, a totalidade do movimento, isto é, da vida. Entanto, a circularidade, para o poeta, não é um componente abstrato, encerrado no simbolismo do número. O comparecimento da dezena em ambas as direçōes, a partir da unidade, simplesmente sela a conformação do poema que, a um só tempo, é círculo, ovo e triângulos.

Se o denário incorpora o simbolismo de renovaçāo e de renascimento, o mesmo podemos dizer do círculo e do ovo. A conformação circular, também ligada à unidade e à perfeição, aliada à circunstância de os dois denários encontrarem-se no centro do poema, ratifica a noção de simetria, de renovação segundo as pegadas de Hermes, isto é, dentro do movimento dos círculos concêntri$\cos$, da unidade dentro da multiplicidade. Ao mesmo tempo, a forma ovular, além de ratificar a postura de Hermes como origem do discurso, conjugada ao círculo, corrobora a trama e a palavra como formas primordiais, porque materializaçōes do ovo do mundo, ou da arte da palavra. Fechado em si e por si, isto é, de fora para dentro e de dentro para fora, é ele a imagem do discurso poético, composto de signos e de símbolos que se mostram e se escondem. Partindo da unidade para a dezena,

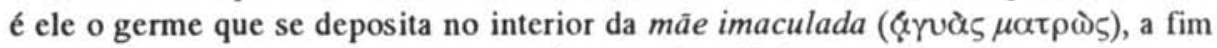
de aprisionar e de tecer a trama, a palavra primordial.

A configuração ovular do poema eleva-o à condição de poemaobjeto e de poema-coisa; não no sentido empregado por Charles Boultenhouse, em que o objeto não exerce as funçōes de significante e de significado, mas um objeto que, aliado às palavras, expressa a própria essência do texto: a palavra e a linguagem sendo e acontecendo. Sob este prisma, o ovo, expressão simbólica da realidade primordial, contém semias de multiplicação dos seres e das palavras, consoante a ordem de Hermes. Além disso, se na alquimia, conforme postula J. van Lennep, é ele o núcleo do universo, encerrando em sua casca os elementos vitais, assim como $o$ vaso hermeticamente fechado, o composto da obra ${ }^{10}$, a conformação do poema, afora ratificar o significado de hermético que o domina pela própria construtura, constitui ele o recipiente que conserva e que gera as palavras e o tecido do discurso desde a sua mais remota origem.

Ao materializar o recipiente e a semente da palavra, a nova trama, o ovo, abriga a inteireza do discurso e dos seres, em essência, porque a totalidade dos entes percebeu identidade através da linguagem. A integridade do tecido é que confere beleza ao discurso. Ao parecer um ser incompleto, afirma

9 - Cf. JUNG, C. G. (1943), p. 148.

10 - LENNEP. J. V. (1966), p. 19.

Signótica 4: 47-60, jan./dez. 1992 
Platão, o mundo não poderia ser belo ${ }^{11}$. Ora, a beleza do poema reside na capacidade de, mediante a arte de nominar e de multiplicar a criação na e pela palavra, conter a totalidade dos seres, de tal maneira que tenhamos um todo sem que as partes padeçam qualquer ameaça à sua constituição física e ontológica.

Como o poema é a palavra acontecendo no tempo e no texto, desde as origens, tanto pelas mãos dos deuses, quanto pelas dos homens, é imperioso registrar que à sua forma ovular, expressão do eterno fazer do discurso, alia-se também a forma triangular. Forma que se estende a todas as direçōes, como a confirmar o ideal estético de simetria e, mormente, a proporção e a harmonia, intrínsecas ao simbolismo do triângulo e à reconstrução do universo através da arte. $\mathrm{O}$ poema assim configurado constitui uma síntese do universo, porquanto abriga todas as possibilidades da linguagem no transcurso do tempo. Cada vez que o homem-poeta, assemelhando-se aos deuses, acelera as múltiplas medidas da canção, o universo é recriado, sobretudo se considerarmos, com Platão, que ao triângulo correspondem os quatro elementos que o compōem. Significativamente, a superfície deste poema corresponde àquela descrita como equivalente à superfície terrestre $\mathrm{e}^{12}$, estabelecendo estreita relação entre a mãe que gera todos os seres, a Terra, e aquela que concebe as palavras.

Passando a outros símbolos que patenteiam a interação semiótica-semântica do texto, verificamos tanto o perfeito imbricamento dos componentes sígnicos e lingüísticos, quanto a propagação de novas semias que confirmam sua riqueza estética e filosófica. Assim, a reiteração do vocábulo pé, no sentido físico, afecto ao homem e aos animais $\mathrm{e}$, no aplicado à métrica, vem demonstrar a incrível correlação dos signos e dos símbolos, porquanto pé alia-se às direções e aos mundos que compõem o universo. Ora, como a superfície do poema representa um tecido de palavras, que interliga as pontas do tempo, mediante a recriação dos objetos na e pela linguagem, o pé confirma a permanência de Hermes na criação, através da palavra, uma vez que ele se retira e não se retira do poemapalavra, agindo e sendo linguagem que (des)vela os seres na tessitura do universo e do discurso, porquanto os pés contêm as energias da palavra e encerram o segredo do $N_{o m} e^{13}$. O que é o segredo do nome, senão a essência do objeto nomeado, senão o lançar-se na existência?

Não nos esquecendo de que a ordem de Hermes - mandou- $a$ multiplicar-se mais e mais - associada às medidas e aos pés errantes que descem pelas encostas do poema, da palavra e de toda a criação prefigura toda a extensāo do criado, consequêencia de o pé sintetizar a totalidade do corpo. Se os pés marcam

11 - PLATON. (1979), p. 1135

12 - Cf. PLATON. (1979), p. 1152.

13 - SOUZENELLE, A. (1984), p. 67. 
o ritmo e as energias do corpo, nada mais significativo que eles se multipliquem ao longo do poema, harmonizando-se com o múltiplo e variado canto das Piérias ( $\tau \alpha v$

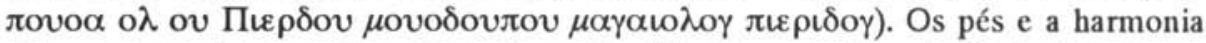
são o ovo sendo, ou seja, a força de realização do germe à maturidade da palavra, à capacidade de a palavra extrair o objeto do nada que antecede o nome e enredá-lo nas malhas do discurso, conferindo-lhe essência e confirmando-lhe a existência.

A fertilização que Hermes proporciona à tessitura da nova trama é total e completa, porque, provinda do alto, desce pelas encostas do poema que, em decorrência de sua conformação elipsóide, é atingido pelo poder da palavra em toda a sua inteireza. Se não bastasse a constituição físico-visual do poema, toda a construtura se apóia em elementos afectos à fecundidade. Além de constituir o germe de que a vida-palavra se desenvolve, uma vez que nenhum objeto é dotado de consistência. ontológica sem prescindir da palavra, sobressaem, ainda, outros componentes cristalizados pela cultura, como símbolos de fecundidade. Dentre eles, o cervo ( $\varepsilon \lambda \circ \phi \circ v)$, ao ligar-se às semias de renascimento, marcado por um ritmo que assinala o eterno fluir das coisas, consolida o papel impresso à nova trama, isto é, multiplicar a criação por intermédio da harmonia e do ritmo das palavras.

Se o cervo procede à fecundação da linguagem, a ovelha (âyuâక) gera, concebe e conserva a palavra nas grutas das Ninfas de tornozelos delgados. Conservar a palavra sob a proteção Ninfas é possibilitar-lhe constante atualidade; no outro universo das ninfas-palavras o envelhecimento não implica a supressão da beleza nem a perda das semias originais. Ademais, a ovelha condensa a simbologia de multiplicação e de vítima, na medida em que as palavras, com o transcurso do tempo, se renovam e se substituem, sem, no entanto, perderem a força arquetípica do logos.

Observamos, por este poema, que já há 300 anos antes de Cristo, o poeta procurava, mediante o consórcio da palavra e dos signos não verbais, a condensação de um linguagem plena. A participação de símbolos matemáticos e esotéricos, em termos artísticos e até religiosos, não constitui um capricho de poeta, mas uma imposição do texto estético, objetivando a consecução de uma linguagem absoluta e integral, capaz de se aproximar da potência e do ato criador dos deuses.

\section{2 - ARTE OU PENTÁCULO?}

A elaboração do poema visual, grosso modo, não constitui um jogo aleatório em que as peças se encaixam segundo as leis do acaso. Segue ela um ordenamento pautado por princípios filosóficos que propiciam a instauraçāo do belo ou, em terminologia mais atual, a instalação da literariedade. Às normas filosóficas seguem-se preceitos fundados na cabala, como a gematria que consiste em aproximar duas palavras que têm o mesmo valor numeral; o notarikon, construção de palavra nova com as iniciais ou as últimas letras das diversas de uma frase, e 
a temura, que se caracteriza pela substituição de uma letra ou de uma palavra por outra, de acordo com combinaçōes alfabéticas chamadas tsirufim ${ }^{14}$. Como resultado, os textos se tornavam essencialmente herméticos, porquanto a leitura implica conhecimentos metalingüísticos (além da linguagem). Os poemas, em decorrência, se convertiam em enigmas.

Durante a Idade Média e mesmo no final da Antiga, os textos visuais, carregados de simbolismos cabalísticos e mandálicos, transformaram-se em objetos dotados de faculdades capazes de atrair forças superiores benéficas ou maléficas, consoante a destinação a que se determinavam. A arte colocava-se a serviço da magia. É evidente que o caráter mágico não elimina o engenho que norteou a estruturação do discurso, possibilitando o aprimoramento dos princípios estéticos inerentes à feitura do poema. Mesmo que, em tese, o texto visasse ao exercício e à prática da magia, a sua essência, ou seja, a conformação visual, a disposição das palavras segundo cálculos geométricos e a conseqüente arquitetura numérica dos vocábulos e da totalidade do texto, transformaram-no em discurso altamente estético e poético. Poético no sentido das produçōes visuais, porquanto é a palavra explorada desde a essência, em todas as potencialidades semiológicas e semânticas.

A arquitetura de um texto esotérico consoante com os cânones da cabala chega, inclusive, a dispensar o consórcio da palavra que, às vezes se converte em mero acessório, uma vez que uma letra, com seu correspondente numérico, pode incorporar e desprender semias próprias. A magia e a arte, nestas circunstâncias, residem exatamente em uma construtura em que a simetria e o sentido esotérico se interdependem, porque enigma, mistério e estética se coproduzem. Uma amostra palpável da união da arte com a magia é a palavra-poema abracadabra, que, segundo Jean Rivière, vem do hebreu abreg ad habra (אבראברברא), que significa: envia seu raio (fogo) até a morte ${ }^{15}$.

O significado, se concordarmos com Chevalier e Gheerbrant que a palavra-triângulo visa a atrair as energias positivas do altos ${ }^{16}$ afigura-se-nos perfeito, porquanto raio e fogo materializam o poder infinito da Divindade. A forma triangular, voltada para baixo, ao simbolizar o próprio homem e o recipiente afunilado por que descem as potestades celestes, sugere que todas as forças devem dirigir-se ao homem e por ele passar. Se a embocadura do triângulo visualiza o objeto que capta as energias, o seu simbolismo, como um todo, o confunde com o Supremo, que se manifesta nos elementos criados que estão em baixo. Deus é um

14 - ALEXANDRIEN, (1983), p. 81

15 - RIVIËRE, J. (1974), p. 54.

16 - Cf. CHEVALIER, J. \& GHEERBRANT, A. (1988), 
triângulo em chamas que incendeia e fecunda, com seus raios, o homem que o invoca:

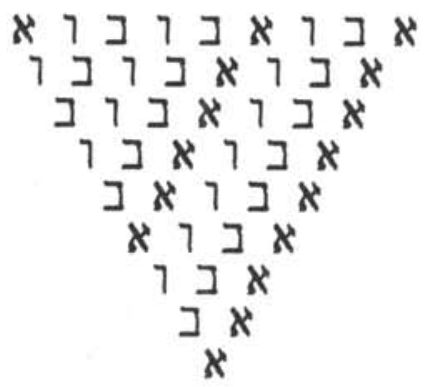

A inversão do triângulo, se considerarmos a sua conformação cônica, se enquandra perfeitamente com a concepção religiosa medieval, que via nas relações do homem com Deus posturas de integral dependência. Ora, se o cone ascendente se correlaciona com a evolução da matéria em direção ao espírito, o descendente, ao atrair, de forma turbilhonante, os raios flamejantes da Divindade, patenteia as limitaçōes e a eterna subordinação do homem ao criador, necessitando, em decorrência, de constante e segura proteção. $\mathrm{O}$ homem ascende a Deus somente por intermédio dos triângulos de aleph $(\aleph)$. Para isso, necessita empreender uma viagem que compreende etapas árduas, até retornar à unidade, ou seja, ao aleph inicial, sobretudo se verificarmos que, enquanto o ângulo ascendente se encontra mais na posição horizontal, o descendente se posiciona verticalmente, como a mostrar que, a despeito de se justaporem, permanece uma insuperável distância entre eles.

Tendo o texto uma configuração triangular, é lógico que ele incorpore as semias inerentes aos predicados semiológicos que lhe são intrínsecos. Entanto, como todos os seus componentes são regidos por preceitos cabalísticos, não somente a ternariedade do triângulo é responsável pela produção de significados; também os atributos do ternário participam da estruturação do poema-talismã. Assim, observamos, de imediato, que, na formação da palavra que se dissolve ao longo do texto, o ternário age de forma intensa. Primeiramente, porque cada letra se apresenta três vezes na extensão do vocábulo, sendo que o aleph $(\mathcal{K})$, a letra primordial, lendo da direita para a esquerda, o abre, o medeia e o fecha. Como o ternário é o número da ação, o aleph $(\aleph)$ triplicado, sendo uma letra sagrada, imagem do próprio Deus ${ }^{17}$, seria a ação de Deus na totalidade de seus raios exercitando e praticando as potencialidades do bem sobre os homens. A repetição ternária das letras aleph $(K)$, bet (ב) e res (ㄱ) permite-lhes reduplicar a trindade a partir da unidade, aleph ( $\aleph)$. Se

17 - Cf. SOUZENELLE, A. (1987) e SKARIATINE, M. V. (1968). 
a palavra-texto, além da invocação à Divindade, visa a atrair os raios que dela emanam, o ternário, sendo um número dinâmico, traduz a ação de aleph $(\aleph)$ sobre as demais letras. Nâo é por acaso que ela se repete em toda a extensão direita do poema, visualizando a descensão da unidade até o múltiplo, ou seja, de Deus às criaturas. Não se trata de uma descensão que lhe vá diminuir a unidade; ao contrário, vai confirmá-la, porquanto o uno não o é sem a existência do múltiplo. Ademais, a reiteração eneádica de aleph $(\mathcal{K})$ eleva-o da unidade à pluralidade, mas uma multiplicidade que lhe devolve a unidade. Sabiamente, a conformação do poematalismã a introduz na ternariedade, a eleva à terceira potência, materializando a ternariedade do triângulo e, ao mesmo tempo, fá-la dobrar-se sobre sim mesma.

Ser três, seis ou nove, sem deixar de ser um, é uma necessidade metafísica de aleph $(\aleph)$ e do próprio texto, uma vez que os raios do ternário chegam à totalidade dos homens através do uno. Além disso, aleph $(\mathcal{K})$, aliado ao um, letra e número masculinos, vão corporalizar os significados ocultos do poema-triângulo, uma vez que aleph $(\aleph)$ e um, conforme postula Annick de Souzenelle, simbolizam a força divina penetrante que experimentamos em seu ato criador à medida que descobrimos o nascimento das diferentes letras ${ }^{18} \mathrm{e}$, no caso, à medida que seus raios se expandem sobre aqueles que invocam a ação da flama celeste.

Sendo aleph $(\aleph)$ a fonte divina que fecunda as demais letras para novamente lhes insuflar a unidade ${ }^{19}$, nada mais lógico que ela se repetisse nove vezes ao longo da linha direita do poema triângulo. Primeiro, o novenário é inegavelmente o número apropriado para ratificar as semias referentes à fonte de que se desprendem os raios que descem aos homens, pois os múltiplos de nove são sempre compostos de números cuja soma é igual a nove ${ }^{20}$. Significa que, por mais que aleph $(\aleph)$ se pluralize ao longo do texto, em momento algum a unidade se vê ameaçada, porquanto nove, aleph ( $\aleph$ ) e um são, no fundo, a mesma mônada que emite os raios em direção ao múltiplo. Além disso, se Deus é aleph (K) e tau (ח), primeira e última letra do alfabeto hebraico, nada mais evidente que tivéssemos o primeiro e o último número simples, para deixar claro que, dentro da mentalidade medieval, suplica-se àquele que é o princípio e o fim de todo o criado, quer sob a ótica do logos ( $\left.\Lambda \delta \lambda_{\circ} \varsigma\right)$, quer sob a ordem dos números, porquanto o verso e o número são inseparáveis na construtura do universo. Através de aleph $(\aleph)$ todas as energias do uno se canalizam para aqueles que lhe imploram as flamas da verdade. Se aleph (K) encerra em si todas as outras letras, a fim de fazê-las participar da unidade, o mesmo ocorre com o número nove que, sendo o último número simples,

18 - SOUZENELLE, A. (1987), p. 29

19 - Idem, p. 30

20 - ALLENDY, R. (1984), p. 258-259. 
contém em si todos os que lhe precedem. Para distribuir as energias, Deus age com todas as suas potencialidades: verbal e numérica, porque é ele logos e número.

A interação aleph-novenário é elaborada sobre princípios semiológicos executados segundo a ciência e a tradição da cabala. Destarte, se aleph $(\aleph)$ se confunde com a mônada e, em conseqüência, com Deus, que se manifesta por intermédio da palavra, o número nove vem corporificá-la, uma vez que é definido como o veículo real e objetivo do poder do Logos, (...) o meio de propagaçāo de todas as vibraçōes cósmicas, aquele que permite suas combinaçōes, suas ressonâncias, suas açōes e realizaçōes recíprocas, em suma, todos os aspectos do universo $v_{i v o}{ }^{21}$. Assim entendida, a conjunção de aleph $(\aleph)$ com o número nove, que the possibilita repetir-se eneadicamente na parte direita do triângulo, vem visualizar e materializar os raios emanados da Divindade. O nove e o aleph ( $\aleph$ ) são as combinaçōes e as ressonâncias das energias que se desprendem do alto. São as forças celestes sendo e acontecendo.

Conquanto a essência do número três dominar a totalidade do texto, também a letra bet (ב) parece fugir a esta estruturação, porquanto é regida pelo binário. Todavia, se observarmos que o fonema bet (ב) se apresenta três vezes na formação da palavra, verificamos que, ao um só tempo, ele se adequa à ternariedade do triângulo e à masculinidade de aleph $(\aleph)$. Primeiro, porque sendo bet (ב) uma letra feminina, ao repetir-se três vezes, mantém a exigência do par, uma vez que sua principal caraterística é a receptividade: receptividade a aleph $(\mathcal{K})$, elemento masculino, e, em decorrência, aos raios emitidos pela Divindade. Bet (ב) não somente não coloca em risco o ternário, como, inclusive, eleva-o à terceira potência, multiplicando no triângulo as energias da mônada. Além disso, se atentarmos para a construtura do poema-triângulo, vamos averiguar, em segundo lugar, que a reciprocidade de aleph-bet, como está escrito nas origens das letras, perdura: aleph ( $)$ e bet (ב) concorrem o mesmo número de vezes na tecedura do texto. Aleph ( $(\aleph)$ coloca diante de bet (ב) a alteridade sem, no entanto, dele se separar, porque o habita, é seu par inseparável.

Se é aleph ( $\times$ ) a mônada, bet ( $\sqsupseteq)$ é a criação, os raios que se desprendem da divindade, tanto que bet $(\beth)$, juntamente com aleph $(\aleph)$, chega ao vértice do triângulo. Entretanto, as energias de bet $(\beth)$ se expandem através de aleph $(\aleph)$, realizando o que Annick de Souzenelle chama mistério de bet ( $コ$ ), ou seja, bet é colocado como outro, separado de aleph $\times$ e é, no entanto, não separado dele. Mistério do 2 que secretamente contém o 1, como o ovo o contém o germe. Mistério da Criação que é chamada a germinar seu Criador, a colocá-lo no mundo, a fim de ser integrada a $E^{22}$. Para que os raios de aleph $(\mathcal{K})$ e da mônada, isto é, da

21 - ALLENDY, R. (1984), p. 170

22 - SOUZENELLE, A. (1987), p. 34 
Divindade, desçam àqueles que a invocam, é imprescindível a integração entre o um e o dois. Somente assim, o uno pode se irradiar sobre o múltiplo.

Essa irra diação se torna mais manifesta, quando verificamos que também a letra res (7), inserida no múltiplo, tem como correspondente numérico o dois e, como simbolismo principal, a receptividade. $\mathrm{O}$ binário permite que ela componha par com aleph ( $\aleph)$, pois, acresce-se ser ela uma letra feminina. A receptividade, por outro lado, possibilita que ela, ao mesmo tempo que recebe eflúvios de aleph $(\aleph)$, também exerça influência sobre ele. Esta arquitetura semióticosemântica se nos aclara ao interligarmos o significado etimológico de אברא ברברא, abreg ad habra, palavra mágica, com um dos simbolismo de res (ㄱ): fogo. Res (ㄱ), sendo fogo, materializa, na construtura do poema-talismã, as energias que são lançadas sobre aqueles que invocam as divindades. Entretanto, como res (7) não chega ao ápice do triângulo, porque múltiplo como os suplicantes, deve atingi-lo por intermédio de aleph $(\mathcal{K})$, ou seja, por intercessão do uno. Dentro do espírito mágico, teológico e filosófico que perpassa a montagem do texto, fica claro que mesmo o múltiplo, para se expandir sobre a multiplicidade, necessita do uno.

Essa irradiação se torna mais evidente, quando verificamos que res (ㄱ), a despeito de ser regida pelo binário, não elimina a ternariedade do triângulo, porquanto contribui triplicemente para a composição do vocábulo que conforma o poema talismânico. Além disso, a repetição novenária de aleph $(\aleph)$, ao início, transforma-o em um símbolo cósmico que, em decorrência, engloba as demais letras. Esta corrente de evolução já fora objetivada pelos fonemas aleph ( $\aleph$ ) e bet (ב), presentes dezesseis vezes, cada um, na conjuntura visual do poema-triângulo. É interessante observar que se trata de uma evolução positiva, uma vez que dezesseis se reduz a sete, $1+6=7$, número da liberação cármica. Destarte, as energias dispendidas por aleph $(\aleph)$, a letra que libera o fogo de res (ㄱ), serão sempre positivas, porque regida pelo número sete.

Res (7), entretanto, colabora somente treze vezes na constituição do poema-talismā. Ora, treze não se configura um número aleatório, conformado à estrutura visual do texto. Na conjunção dos signos, o número treze se integra à geração de semias destinadas à ampliação e à confirmação do campo de raio ou de fogo. Assim, o número treze só poderia estar afecto a res (ㄱ) que, ao aliar-se ao simbolismo de fogo, é também atividade, movimento. Este número, afirma-nos René Allendy, representa um princípio de atividade, 3, se exercendo na Unidade de um todo, 10, que ele contém e que não faz produzir, se não um ciclo de renovaçōes perpetuamente idênticas $(1+3=4)^{23}$.

Acima das particularidades numéricas de cada letra, observamos que, em conjunto, as letras compõem uma enêada, associando as energias individuais

23 - ALLENDY, A. (1984), p. 356. 
às vibraçốes cósmicas de aleph $(\aleph)$, à harmonia do triângulo que as conduz à multiplicidade dos homens que se dirigem, súplices, à Divindade. Mas a ternariedade e a lógica do texto não se atêm somente ao nível das letras, estendem-se também, à arquitetura do poema- triângulo. É para atestá-lo que devemos verificar a soma de todas as letras que erigem o poema: quarenta e cinco, ou seja, $4+5=9$, número que robustece os simbolismos da unidade cósmica corporificada pelo aleph $(\mathcal{K})$. Ademais, todas as semias do número quarenta e cinco, descritas por René Allendy, fazem parte da organizaçāo física do poema: Nós temos aqui a vida, 5 , nas revoluçōes do mundo, 40 , se dispersando ao infinito, mas tendendo à solidariedade do novenário $(4+5$ =9). Este número se afigura um quíntuplo novenário $(45=5 \times 9)$, simbolizando esta solidariedade cósmica que se exprime na vida de todos os seres ${ }^{24}$. É seguindo esta ótica que o texto é um talismã, porque todas as letras, juntamente com a palavra mágica e com o triângulo, materializam as energias e todas as forças cósmicas emanadas da Divindade.

A despeito de os simbolismos impressos a cada signo interligarem-se às semias dos talismãs e dos pentáculos, a arquitetura do texto obedece a um engenho cabalístico que o insere na isotopia do poético, notadamente se observarmos que o poema visual deve pautar pelo velamento de um mistério, de um enigma, seja ideológico, teológico ou filosófico. Importa que a palavra, as letras e a conformação visual sejam signos densos de significados, que toda a cadeia dos signos seja construída segundo um campo semântico determinado, de tal forma que tudo se processe de conformidade com as leis da simetria, imprescindíveis à instalaçẫo do belo, e consoante as leis da cabala, que direcionam a conjunção dos signos esotéricos. Destarte, as letras, na totalidade do poema, não são meros fonemas que se aglutinam para compor a palavra; são símbolos que se conjugam para gerar significados que se emaranham à integridade do objeto estético-esotérico. Chegam mesmo a ultrapassar a ordem semântica da palavra, como se cada letra fosse um lexema independente que se amalgama ao texto semiótico. A letra, assim entendida, além de carregar as próprias semias, incorpora as semias dos números da figura em que está inserida, formando um objeto semiótico todo semântico.

\section{ABSTRACT}

This study intends to show, through esoteric analysis related to cabala and mandala, how the structure of visual Greek poems and Hebraic pentacles follow a creative process which is typical of the poetic text, even though they were created with religious intentions aiming at magic.

24 - ALLENDY, R. (1984), P. 386-387. 


\section{REFERÊNCIAS BIBLIOGRÁFICAS}

ALLEXANDRIEN. História da filosofia oculta. Lisboa: Ediçōes 70, 1983.

ALLEAU, René. A ciência dos símbolos. Lisboa: Ediçōes 70, 1976.

ALLENDY, Docteur René. Le symbolisme des nombres: essai d'arithmosophie. Paris: Chacornac Frère, 1984.

ARISTÓTELES. Obras. Madrid: Aguilar, 1973.

BOULTENHOUSE, Charles. Poemas in the shapes of things. Art News Annual, New York, v. 28 , p. $65-173$,

CHEVALIER, Jean; GHEERBRANT, Alain. Dicionário de símbolos. Rio de Janeiro: J. Olympio, 1988.

EVOLA, Julius. La tradizione ermetica. Roma: Mediterranee, 1991.

FERNANDES, José. Dimensōes da literatura goiana. Goiânia: CERNE, 1992.

GHYKA, Matila C. Le nombre d'or. Paris: Gallimard, 1959.

HATHERLY, Ana. A experiência do prodígio. Lisboa: Imprensa Nacional, 1983.

HOCKE, Gustav René. Il manierismo nella letteratura. Milano: Il Saggiatore, 1965.

JUNG, Carl G. Psicología y alquimia. Buenos Aires: Santiago Rueda, 1943.

KEPES, George. El lenguage de la visión. Buenos Aires: Infinito, 1969.

PLATON. Obras completas. Madrid: Aguilar, 1979.

RIVIÈRE, Jean. Amuletos, talismanes y pentáculos. Barcelona: Martinez Rocha, 1974.

SAFRAN, Alexandre. La cábala. Barcelona: Martinez Roca, 1976.

SELIGMANN, Kurt. História da magia. Lisboa: Ediçōes 70, 1979.

SKARIATINE, Michel Vladimirovitch. La langue sacré. Paris: Maisonneuve \& Larose, 1984.

SOUZENELLE, Annick de. $O$ simbolismo do corpo. Sāo Paulo: Pensamento, 1984.

. La lettre chemin de vie. Paris: Dervy-Livres, 1987.

WARRAIN, Francis. La Théodicée de la kabbale. Paris: Guy Trédaniel, 1984.

YLLERA, Alicia. Estilística, poética e semiótica literária. Coimbra: Almedina, 1979. 